\title{
ソルダ供給量に及ぼすソルダペースト中の平均粉径の影響
}

\author{
荘司 郁夫*, 白鳥 祐司 ${ }^{*}$, 宮崎 誠 ${ }^{* *}$
}

\section{Influence of the Diameter of Solder Powder in Solder Paste on the Applied Solder Volume by Paste Printing}

$$
\text { Ikuo SHOHJI*, Yuji SHIRATORI* and Makoto MIYAZAKI** }
$$

\footnotetext{
*群馬大学工学部（テ376-8515 群馬県桐生市天神町 1-5-1)

**沖電気工業株式会社FSC システム機器本部（テ370-8585 群馬県高崎市双葉町 3-1）

* Faculty of Engineering, Gunma University (1-5-1 Tenjin-cho, Kiryu-shi, Gunma 376-8515)

**Terminal System Division, FSC, OKI Electric Industry Co., Ltd. (3-1 Futaba-cho, Takasaki-shi, Gunma 370-8585)
}

\begin{abstract}
The influence of powder size in solder paste on the solder volume applied by paste printing has been examined. The applied solder volume increased with decreasing the average diameter of solder powder which are contained in the solder paste. The solder paste with fine solder powder easily caused a solder bridging failure between the electrodes for a fine pitch QFP after reflow soldering. The measurement value of the applied solder volume was good accordance with the approximate half of the calculated volume using the close-packed model in which the powder with the average diameter is close-packed in the opening space of the stencil.
\end{abstract}

Key Words: Paste Printing, Solder Paste, Fine Powder, Lead-Free

\section{1. 緒 言}

1980年代より開始され，現在の実装技術の主流たる表面 実装技術1)においては，ソルダペーストが使用される。ソ ルダペーストは, ソルダ粉とペースト状フラックスの混合 物からなり, 一般にソルダペースト中のソルダ粉は, 球形 粉が使用され， $25 \mu \mathrm{m} \sim 42 \mu \mathrm{m}$ の範囲程度の粒度分布をもつ ものが使用される2)。従来, ソルダペーストは, 表面実装 部品の搭載用に, ペースト印刷法により, プリント配線板 の電極上に供給されてきたが, 搭載部品の小サイズ化およ びファインピッチ化に対応すべく, 平均ソルダ粉径が $15 \mu \mathrm{m}$ 程度のソルダペーストが開発され, フリップチップの搭載 用にも使用されるようになってきだ) 6)。また，最近では， 半導体パッケージあるいはベアチップのバンプ形成用に, 平均ソルダ粉径が $10 \mu \mathrm{m}$ 以下のものも検討されるように なっている6)。そこで, 本研究では, 微細ソルダ粉を用い たペースト印刷技術の印刷特性を調查することを目的とし て, ソルダ粉径の異なるソルダペーストを作成し, 表面実 装部品搭載用電極上にペースト印刷を実施した。特に, ソ ルダ供給量に及ぼすソルダペースト中のソルダ粉径の影響 について調查したので，その結果について報告する。

\section{2. 実験方法}

本研究では, Table 1 に示す 3 種類のソルダ平均粉径を持 つSn-3.0mass\% Ag-0.5mass \%Cu のソルダペーストを準備し
た。さらに, Fig. 1には, Table 1に示した各ソルダペース トのソルダ粉の粒度分布を示した。なお, 本研究で使用し たソルダペースト用のフラックスは, 無洗浄用 RMA タイ プのものとした。

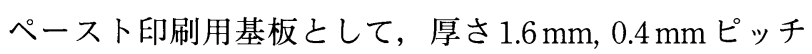
および $0.3 \mathrm{~mm}$ ピッチ QFP (Quad Flat Package) および 0603 チップ搭載用の $\mathrm{Cu}$ 電極を有する FR-4 基板を用いた。Fig. 2 に, 評価用 FR-4 基板のパターンを示す。各 $\mathrm{Cu}$ 電極のサイ ズは, $0.4 \mathrm{~mm}$ ピッチ $\mathrm{QFP}, 0.3 \mathrm{~mm}$ ピッチ $\mathrm{QFP}$ ，および 0603 チップ用電極部に対し，それぞれ， $1.46 \times 0.19 \mathrm{~mm}, 1.45 \times$ $0.13 \mathrm{~mm}, 0.25 \times 0.33 \mathrm{~mm}$ である。また, $\mathrm{Cu}$ 電極およびソルダ レジストの平均厚みは, それぞれ, $60 \mu \mathrm{m}$ および $52 \mu \mathrm{m}$ で ある。なお, $\mathrm{Cu}$ 電極の表面処理は, 水溶性プリフラックス 処理とした。

メタルマスクは, アディティブ法により穴加工が行われ た $\mathrm{Ni}$ 製のもので, メタルマスク厚が $150 \mu \mathrm{m}$ および $120 \mu \mathrm{m}$

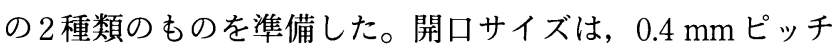
$\mathrm{QFP}$ および $0.3 \mathrm{~mm}$ ピッチ $\mathrm{QFP}$ 用パターンに対しては, 電極

Table 1. Solder paste type

\begin{tabular}{cccc}
\hline $\begin{array}{c}\text { Composition } \\
(\text { mass } \%)\end{array}$ & $\begin{array}{c}\text { Spec. of } \\
\text { diameter of } \\
\text { powder }\end{array}$ & $\begin{array}{c}\text { Average of } \\
\text { diameter of } \\
\text { powder }(\mu \mathrm{m})\end{array}$ & $\begin{array}{c}\text { Flux content } \\
(\text { mass } \%)\end{array}$ \\
\hline & under $10 \mu \mathrm{m}$ & 8.2 & 10.5 \\
Sn-3Ag-0.5Cu & under $15 \mu \mathrm{m}$ & 11.3 & 10.5 \\
& $25-42 \mu \mathrm{m}$ & 39.3 & 10.0 \\
\hline
\end{tabular}




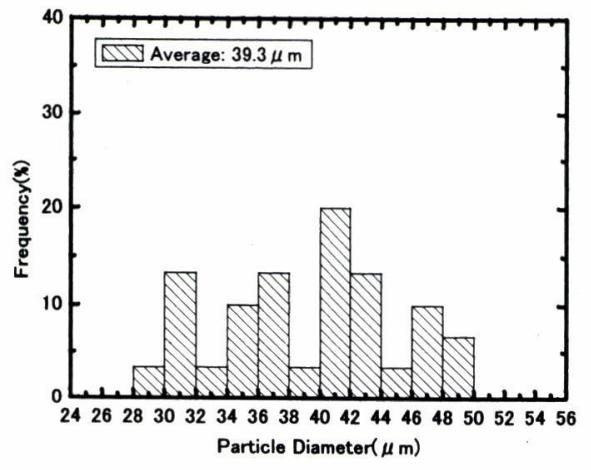

(a)

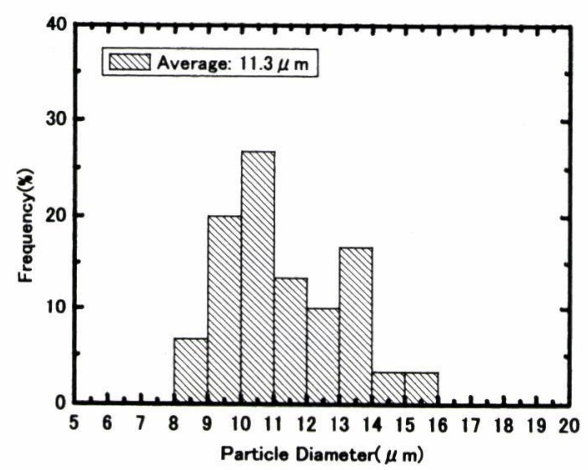

(b)

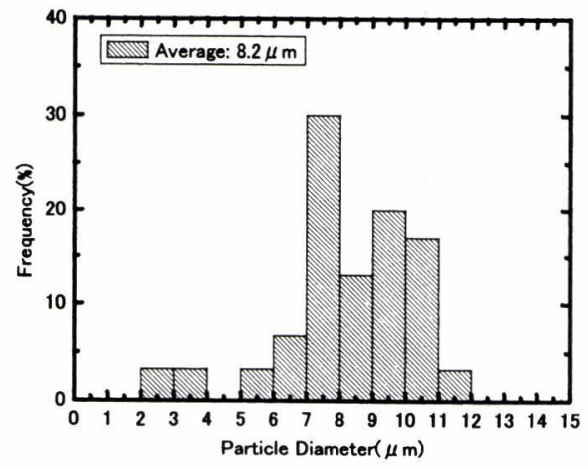

(c)

Fig. 1 Particle-size distributions of powders, which average diameter are $39.3 \mu \mathrm{m}$ (a), $11.3 \mu \mathrm{m}$ (b) and $8.2 \mu \mathrm{m}$ (c), respectively

サイズと同一サイズとし，0603チップ用電極部に対しては, $0.23 \times 0.33 \mathrm{~mm}$ とした。Table 2 に, 本研究で実施した印刷 条件をまとめて示す。なお，スキージは，ウレタンゴム製 スキージを使用した。

ソルダペースト印刷後の基板に対して，リフロー炉を用 いて, リフローソルダリングを行った。リフロー条件は, ピーク温度 $224^{\circ} \mathrm{C}$ と, $217^{\circ} \mathrm{C}(\mathrm{Sn}-3 \mathrm{Ag}-0.5 \mathrm{Cu}$ の溶融開始 温度）以上の保持時間が $29 \mathrm{~s}$ であった。リフローソルダリ ング後に, ソルダリング部におけるブリッジやソルダボー ル1)等のソルダリング不良の発生の有無を評価した。さら に，0603 チップ搭載用電極に供給されたソルダ量を評価す るために, X,Y,Z軸方向の測定機能付き光学顕微鏡を用い

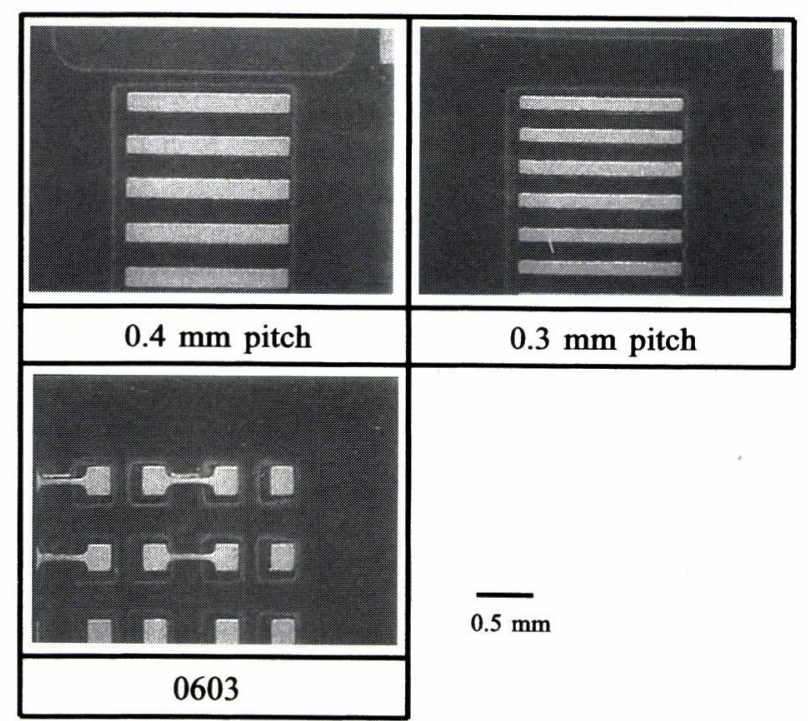

Fig. $2 \mathrm{Cu}$ patterns in the printed circuit board

Table 2. Conditions of paste printing

\begin{tabular}{lc}
\hline \multicolumn{1}{c}{ Parameter } & Setting value \\
\hline Gap between stencil and board & $0 \mathrm{~mm}$ \\
Printing pressure & $2.0 \mathrm{kgf} / \mathrm{cm}^{2}$ \\
Printing speed & $30 \mathrm{~mm} / \mathrm{s}$ \\
\hline
\end{tabular}

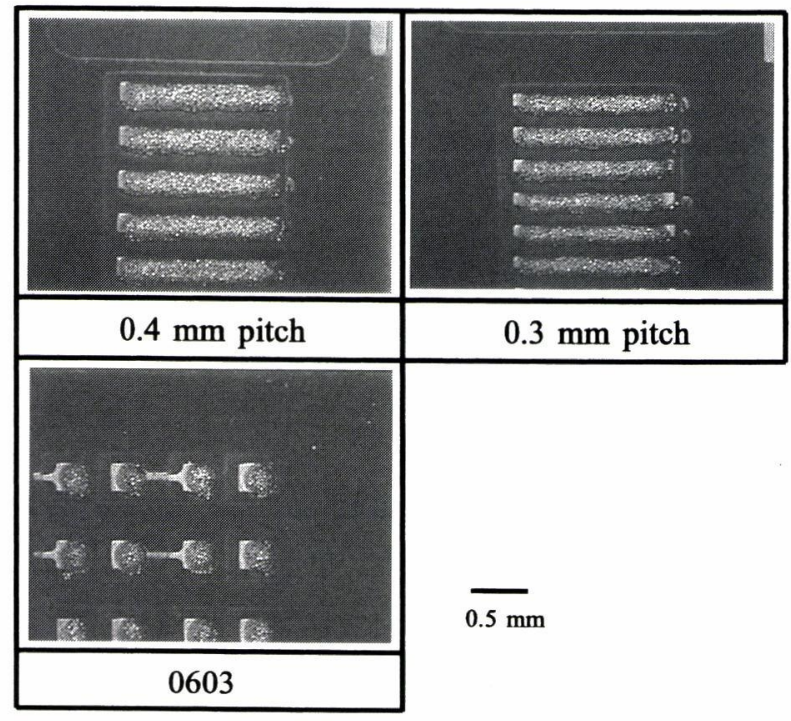

Fig. 3 General views after paste printing using solder powder with $39.3 \mu \mathrm{m}$ diameter (stencil thickness: $120 \mu \mathrm{m}$ )

て, リフローソルダリングによって形成されたソルダバン プの高さおよび底辺部の直行する 2 方向の径を測定した。 そして, それらの測定值を用いて, ソルダバンプの形状を 球の一部として近似することにより, 供給ソルダ量を求め た。

\section{3. 実験結果および考察}

\section{1 印刷結果}

Fig. 3 およびFig. 4 に， $120 \mu \mathrm{m}$ 厚のメタルマスクを用いて 


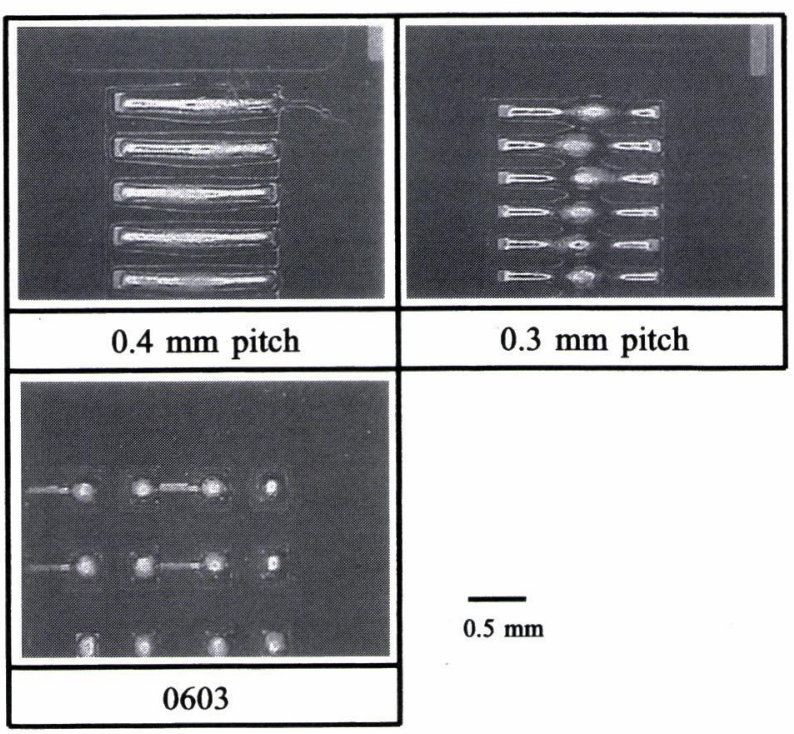

Fig. 4 General views after reflow soldering for the same site shown in Fig. 3

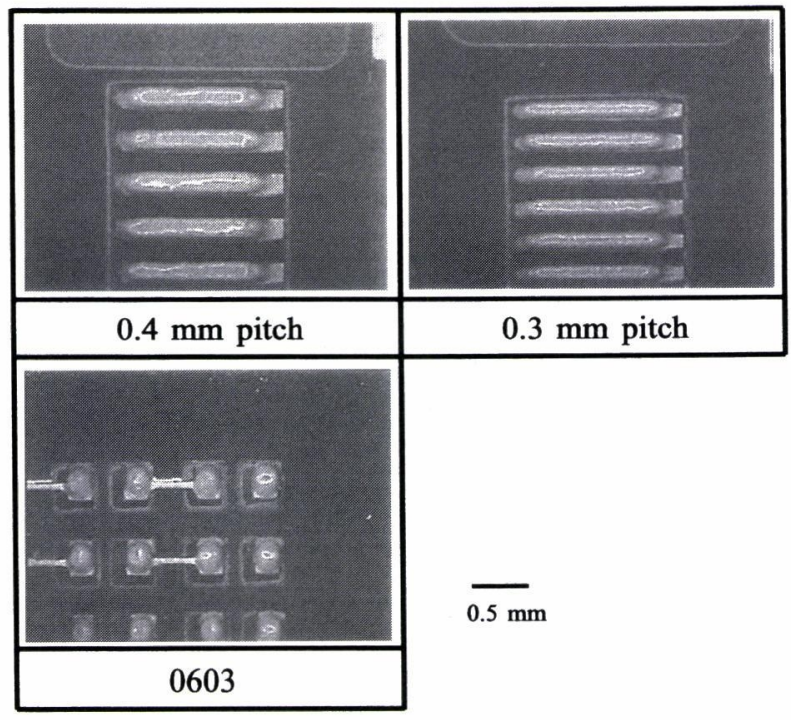

Fig. 5 General views after paste printing using solder powder with $8.2 \mu \mathrm{m}$ diameter (stencil thickness: $120 \mu \mathrm{m}$ )

平均粉径 $39.3 \mu \mathrm{m}$ のソルダペーストを印刷した基板の印刷 後およびリフローソルダリング後の同一箇所の外観観察像 をそれぞれ示す。 $0.3 \mathrm{~mm}$ ピッチ QFPの電極パターンにおい て, 電極中心部へのはんだの集中が認められる以外は，ブ リッジ等の不具合は, 認められない。

Fig. 5 およびFig. 6 に， $120 \mu \mathrm{m}$ 厚のメタルマスクを用いて 平均粉径 $8.2 \mu \mathrm{m}$ のソルダペーストを印刷した基板の印刷後 およびリフローソルダリング後の同一箇所の外観観察像を それぞれ示す。平均粉径 $39.3 \mu \mathrm{m}$ の結果と比較すると, ソ ルダ粉末の微細化に伴う電極外への微細粉の残留(ソルダ ボール1) (は認められないが， $0.3 \mathrm{~mm}$ ピッチ $\mathrm{QFP} の$ 電極パ ターンにおいて，ブリッジの発生が認められる。Table 3 に，リフローソルダリング後のブリッジ発生の有無をまと

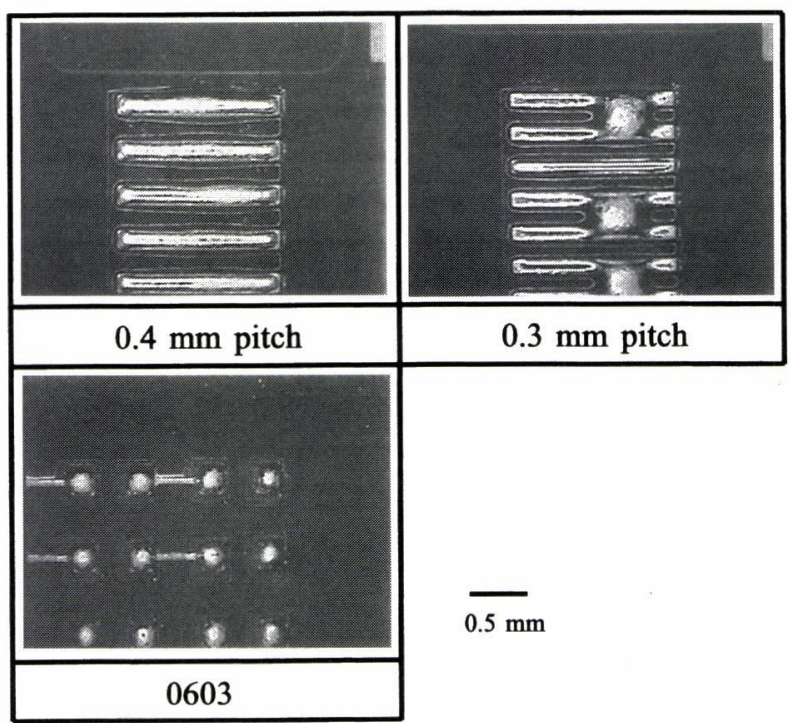

Fig. 6 General views after reflow soldering for the same site shown in Fig. 5

Table 3. Summary of inspection results after reflow soldering

\begin{tabular}{|c|c|c|c|}
\hline $\begin{array}{c}\text { Stencil } \\
\text { thickness }(\mu \mathrm{m})\end{array}$ & $\begin{array}{c}\text { Diameter of } \\
\text { powder }(\mu \mathrm{m})\end{array}$ & Pad pattern & $\begin{array}{c}\text { Soldering } \\
\text { results }\end{array}$ \\
\hline \multirow{6}{*}{150} & \multirow[t]{2}{*}{39.3} & $0.4 \mathrm{~mm}$ pitch & 0 \\
\hline & & $0.3 \mathrm{~mm}$ pitch & 0 \\
\hline & \multirow[t]{2}{*}{11.3} & $0.4 \mathrm{~mm}$ pitch & $x$ \\
\hline & & $0.3 \mathrm{~mm}$ pitch & $x$ \\
\hline & \multirow[t]{2}{*}{8.2} & $0.4 \mathrm{~mm}$ pitch & $x$ \\
\hline & & $0.3 \mathrm{~mm}$ pitch & $x$ \\
\hline \multirow{6}{*}{120} & \multirow[t]{2}{*}{39.3} & $0.4 \mathrm{~mm}$ pitch & 0 \\
\hline & & $0.3 \mathrm{~mm}$ pitch & 0 \\
\hline & \multirow[t]{2}{*}{11.3} & $0.4 \mathrm{~mm}$ pitch & 0 \\
\hline & & $0.3 \mathrm{~mm}$ pitch & 0 \\
\hline & \multirow[t]{2}{*}{8.2} & $0.4 \mathrm{~mm}$ pitch & 0 \\
\hline & & $0.3 \mathrm{~mm}$ pitch & $\times$ \\
\hline
\end{tabular}

$O$ : No bridge, $\times$ : Bridge

めた。メタルマスク厚 $120 \mu \mathrm{m}$ の場合には，平均粉径 $8.2 \mu \mathrm{m}$

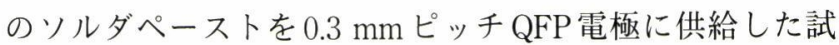
料においてのみ，ブリッジの発生が認められたが，メタル マスク厚が $150 \mu \mathrm{m}$ の場合には，平均粉径 $11.3 \mu \mathrm{m}$ 以下のソ ルダペーストを用いると $0.4 \mathrm{~mm}$ および $0.3 \mathrm{~mm}$ ピッチ $\mathrm{QFP}$ のいずれの電極パターンにおいてもブリッジが発生するよ うになった。これは, メタルマスク厚の増加に伴い, 供給 ペースト量が増えるため, ブリッジが発生しやすくなった ものと考える。また，微細粉末を用いたほうが，ブリッジ の発生が起こりやすくなる傾向を示すのは, 後述するよう に，平均粉径の減少に伴い，供給はんだ量が増加すること に起因するものと考える。

\section{2 ソルダ供給量}

Fig. 7 は, 0603 チップ搭載用電極パターン上に供給され 


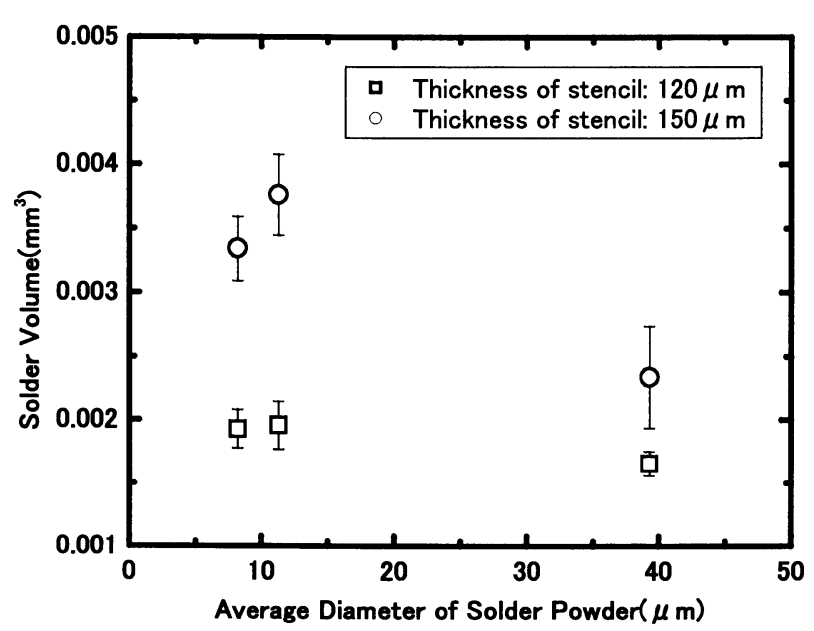

Fig. 7 Relationship between the solder volume applied on the electrode for the 0603 chip and the average diameter of powder in solder paste

Table 4. Evaluation model for applied solder volume

\begin{tabular}{cl}
\hline Model type & \multicolumn{1}{c}{ Details } \\
\hline Model 1 & $\begin{array}{l}\text { (Stencil opening volume }) \times(\text { Volume content of solder } \\
\text { powder in solder paste) }\end{array}$ \\
Model 2 & Closed pack model using powder with average diameter \\
\hline
\end{tabular}

たソルダ量と, ソルダペースト中の平均粉径との関係を示 す。Fig. 7 より,ソルダペースト中の平均粉径が減少する と，供給されるソルダ量はメタルマスク厚が $120 \mu \mathrm{m}$ および $150 \mu \mathrm{m}$ いずれの場合にも，増加する傾向を示すことがわか る。

平均粉径とソルダ供給量との関係を評価するために, Table 4 に示した2つのモデルを用いて考察を行った。モデ ル 1 は, 簡易的な供給量評価法であり, ソルダ供給量は, メタルマスクの開口部体積に, ソルダペースト中における ソルダ粉末の体積比を乗じた式にて与えられる。本研究で は，Sn-3Ag-0.5Cuソルダおよびソルダペースト中のフラッ

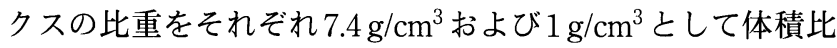
を求めた。また，モデル2では，平均粉径を持つソルダ粉 をメタルマスクの開口空間中に, 剛体球の最密充てんモデ ル7に従って配置し, 充てん個数よりソルダ供給量を求め ている。

両モデルにより評価したソルダ供給量と平均粉径との関 係を，Fig. 7 に示した測定值と共に，Fig. 8 に示す。Fig. 8 より，モデル 1 による評価法では，供給ソルダ量はソル夕゙ ペースト中のフラックス含有量に依存して変化するため, 平均粉径に対しては，ほとんど変化は認められず，本研究 で得られたような傾向は認められないことがわかる。一方， モデル 2 によるソルダ供給量の評価值は，その值は測定值 よりも大きくなるものの，傾向的には，測定值と同様の傾 向，すなわち平均粉径の減少に伴い，ソルダ供給量が増加 する傾向を示した。さらに，メタルマスク厚が $150 \mu \mathrm{m}$ およ び $120 \mu \mathrm{m}$ のいずれの場合においても，モデル 2 から得られ

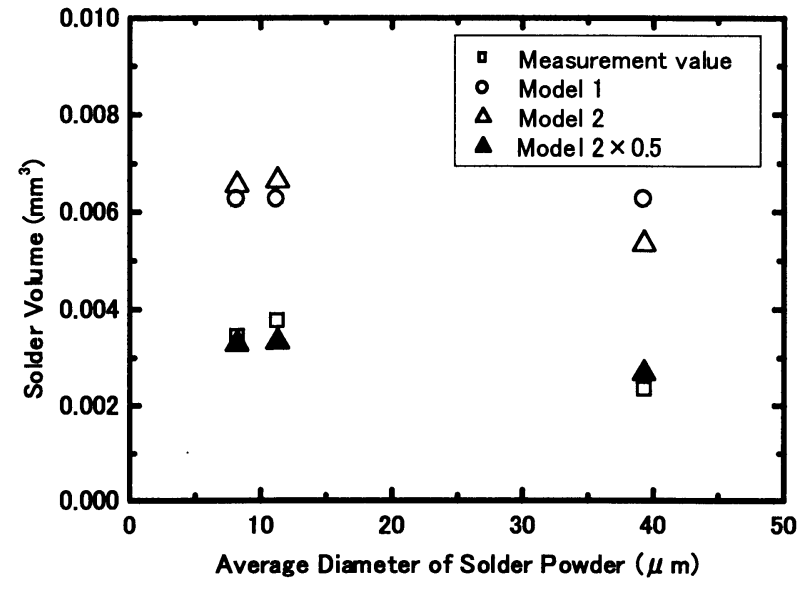

(a) Stencil thickness: $150 \mu \mathrm{m}$

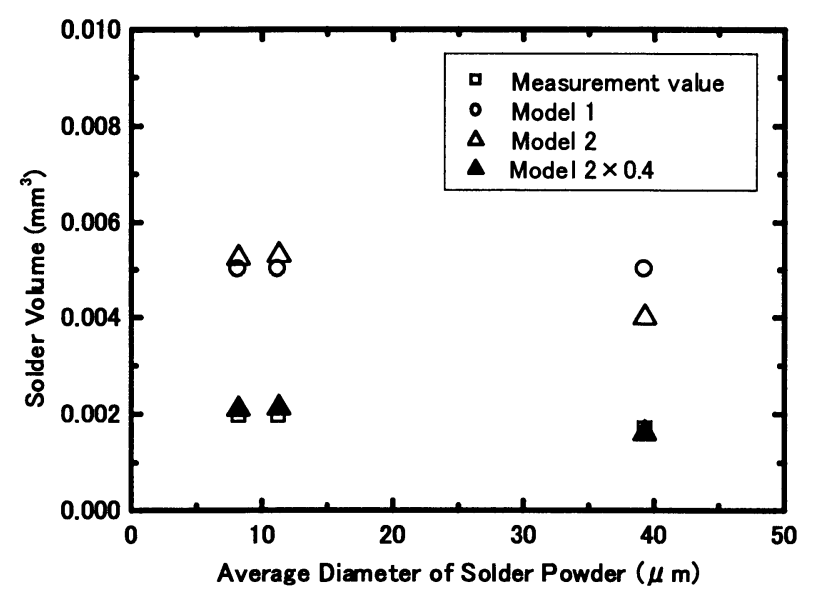

(b) Stencil thickness: $120 \mu \mathrm{m}$

Fig. 8 Evaluation results for applied solder volume using model 1 and model 2 specified in Table 4

るソルダ供給量におよそ $1 / 2$ 程度の補正係数を乗じること により，測定值とモデル 2 にる計算值は，よい一致を示 すことが明らかとなった。

$\mathrm{Da} \mathrm{He}$ らは, 平均粉径 $13.1 \mu \mathrm{m}$ から $33.8 \mu \mathrm{m}$ のソルダペー ストを対象として，ペースト印刷の際にメタルマスクの開 口部に供給されるソルダ体積を，モンテカルロ法を用いて 粒度分布を考慮したシミュレーションにより求めている8)。 その計算結果によれば, メタルマスク厚が $120 \mu \mathrm{m}$ の場合, 平均粉径が $13.1 \mu \mathrm{m}$ から $33.8 \mu \mathrm{m}$ まで大きくなるにつれ，開 口部体積に対する供給ソルダの充てん率は，0.4程度から 0.3 程度に減少する ${ }^{8)}$ 。本研究のモデル 2 の結果においては, 平均粉径が $8.2 \mu \mathrm{m}$ から $39.3 \mu \mathrm{m}$ まで変化すると, 開口部体 積に対する供給ソルダの充てん率は，0.58から 0.43 に減少 する。したがって, 粒度分布も考慮した実際の供給ソルダ 量は，平均粉径のソルダ粉を最密に充てんする場合の 7 割 程度となるものと考えられる。本研究においては，電極上 に供給されるソルダ量の測定値は，最密充てんモデルにて 評価した值のおよそ $1 / 2$ 程度となった（Fig. 8参照）。測定 值が, 計算值の $1 / 2$ 程度の值となることに関しては, 今後, 
さらなる検討が必要であるが, 主要因としては, ペースト 印刷時のメタルマスクコーナー部へのソルダペーストの残 留, ウレタンゴムスキージ使用によるペースト印刷時のソ ルダペーストの掻き出し, 銅電極パッド側面部へのソルダ の供給などが考えられる。

以上の結果より, ソルダペースト中の平均ソルダ粉径が 減少すると同一メタルマスク開ロサイズに対しては，供給 ソルダ量が増加する傾向を示すことが明らかとなった。実 際， $0.3 \mathrm{~mm}$ ピッチおよび $0.4 \mathrm{~mm}$ ピッチ QFP搭載用電極に おいては，微細粉ペーストを用いるとブリッジが発生しや すくなる傾向が観察された（Table 3参照）。そのため, 微 細粉末を用いたソルダペーストを使用する場合には, ペー スト印刷時のソルダの過剩供給を防止するため, メタルマ スク厚を薄くしたり, 開ロサイズを小さくする等の対処が 必要亡なるものと考える。

\section{4. 結 言}

本研究では, 微細ソルダ粉を用いたソルダペーストの印 刷特性を調查することを目的として, ソルダ粉径の異なる ソルダペーストを用いて, ソルダ供給量に及ぼすソルダ ペースト中のソルダ粉径の影響について調査した。その結 果, 平均ソルダ粉径が減少するのに従い, 供給ソルダ量は 増加する傾向を示すことが明らかとなった。この傾向は, 平均粉径を持つソルダ粉をメタルマスクの開口空間中に, 剛体球の最密充てんモデルに従って配置するモデルを利用 して供給ソルダ量を評価することにより, 解釈が可能とな ることが明らかとなった。

\section{謝 辞}

本研究を遂行するにあたり, ホソカワ粉体工学振興財団 より研究助成を受けていることを付記し，謝意を表します。

(2003.5.1-受理)

\section{文献}

1) “標準マイクロソルダリング技術”, 日本溶接協会マイクロ ソルダリング教育委員会編，日刊工業新聞社， 2002

2) J. H. Lau and Y. H. Pao: "Solder Joint Reliability of BGA, CSP, Flip Chip, and Fine Pitch SMT Assemblies”, McGraw-Hill, 1997

3) K. Gilleo: “Area Array Packaging Handbook”, McGraw-Hill, 2001

4) S. Fujiuchi and K. Toriyama: "Collective Screen Printing for Carrier Bump and SMT Pads”, Proc. of IEMT Symposium, pp. 109-112, 1995

5) 鳥山和重, 藤内伸一, 折井靖光 : “ペースト印刷法による フリップチップ接合技術の開発”, Proc. of Mate '99, pp. 177-182, 1999

6) 笠原智彦, 澤 和憲, 高橋義之, 大野隆生：“マイクロ接 合の現状と予測”，第33回マイクロ接合研究委員会ソルダ リング分科会資料, pp. 39-49, 2002

7) 杉本孝一, 長村光造, 山根壽己, 牧 正志, 菊池潮美, 落 合庄治郎，村上陽太郎：“材料組織学”, 朝倉書店, 1991

8) D. He, N. N. Ekere, B. Salam, D. Rajkumar and G. Jackson: "Monte Carlo Study of Solder Paste Microstructure and UltraFine-Pitch Stencil Printing”, Journal of Materials Science: Materials in Electronics, 14, pp. 501-506, 2003 